\title{
Den ortodokse arv. Perspektiver på Ruslands teologiske tradition
}

\author{
Sten Hartung \\ København: Fønix 2019 \\ 479 sider. ISBN 9788793600119
}

Omtalt av Caroline Serck-Hanssen [ph.d. i kunsthistorie, faglitterær forfatter og kulturformidler, serckhanssen@hotmail.com]

I en tid da den ortodokse kirken atter har fătt betydelig innflytelse i det russiske samfunnet, er det viktig med økt kunnskap om landets nasjonalkirke. Det er derfor kjærkomment med en utgivelse på dansk om dette emnet, som få skandinaver har dypere kjennskap til. Den protestantiske presten Sten Hartung har skrevet en svært innholdsrik bok, der han presenterer utvalgte aspekter ved Russlands ortodokse arv. Som den teolog han er, interesserer han seg naturlig nok særlig for teologihistorien. Men forfatterens prosjekt er langt mer vidtfavnende enn det bokens undertittel indikerer. Hartung legger nemlig også stor vekt på kirkehistoriske hendelser. Linjene føres helt fra Kyrillos og Methodios’ misjonsarbeid blant sørslaverne på 860-tallet og frem til dagens Russland, der det bysantinske idealet om symfonia (samklang) mellom kirke og stat har fått ny aktualitet. Helt på tampen rekker han å sneie innom den kirkelige Ukraina-konflikten, som eskalerte høsten 2018. Innimellom alt dette har han også funnet plass til detaljerte omtaler av en rekke ikonmotiver og litterære verk.

Helt sentrale poenger og perifere detaljer avløser hverandre til stadighet $\mathrm{i}$ denne rikt sammensatte collagen av en bok. Dette giør at den oppleves som ujevn og nokså tilfeldig sammensatt. I mange tilfeller er det dårlig samsvar mellom betydningen av et emne og den plassen det får. De lange linjene blir dermed lett borte for leseren i mylderet av stort og smått. For eksempel er fremstillingen av det store skismaet innen den russiske kirken på 1600-tallet overflatisk og anekdotepreget, mens metropolitt Filarets katekisme fra 1839 tilgodeses med en analyse på hele elleve sider. Forfatteren utga i 2018 en kommentert utgave av nettopp dette verket.

Boken kunne med fordel ha vært både kortet ned og strammet opp. På den annen side er det prisverdig at all denne detaljkunnskapen om utvalgte sider ved Russlands ortodokse arv nå foreligger mellom to permer. Det er også positivt at Hartung søker å nå ut til den interesserte allmennhet giennom et lett tilgjengelig språk. Noen steder blir stilen dog i overkant sleivete: Om kirkefaderen Basilios den store får vi vite at han var «klar i spyttet». En annen pussig formulering som gjentas 
flere steder, finner vi i omtalen av dogmet om Jesu to naturer. Det utlegges som at han er «100 procent Gud og 100 procent menneske» (s. 92). Den forfulgte og splittede russiske kirke anno 1927 karakteriseres som "groggy» (s. 314). Slik sjømannsjargong virker malplassert her, med mindre forfatteren vil formidle at kirkeledelsen svimet rundt i vodkarus, noe som neppe er hans intensjon. Under Putin har imidlertid «en kæmpe appelsin faldt ned i kirkens turban» (s. 422)!

På bakgrunn av sin interesse for kunst (Hartung har bachelorgrad i kunsthistorie) er det naturlig at ikonmaleriet står hans hjerte nær. Gjennom et i overkant nærsynt fokus på noen utvalgte ikonmotiver blir temaet fragmentarisk presentert. Jeg savner en redegjørelse for konteksten de enkelte motivene vanligvis inngikk i utsmykningen av kirkerommet som helhet og oppbygningen av ikonostasen. Ta for eksempel ikonet Kristi forklaring på berget. Dette transfigurasjonsmotivet omtales som «et av de mest populære og udbredte» i Russland. I virkeligheten tilhører det en serie motiver viet kirkeårets fremste høytider, som vanligvis utgjør en egen rad på ikonostasen. Det er derfor ikke grunnlag for å hevde at akkurat dette enkeltstående motivet er så mye mer vanlig enn de øvrige festdagsikonene. Derimot har flere forskere interessert seg spesielt for fremstillinger av Kristi forklaring, som blir sett i sammenheng med fremveksten av den monastiske hesykhasmebevegelsen i Russland fra slutten av 1300-tallet. Dette poenget nevnes dog ikke i boken. Den mystiske teologien, som spiller en viktig rolle i den russisk-ortodokse tradisjonen, blir i det hele tatt nokså sparsomt belyst i Hartungs fremstilling.

Forfatteren lener seg tungt på Annika Hvithamars bok Ruslands ikoner, som jeg forøvrig anmeldte i Nordisk Østforum nr. 3, 2010. Imidlertid savner jeg henvisninger til mer kjente verk på feltet, så som Leonid Ouspensky og Vladimir Losskys bok The Meaning of Icons (1982). Det er en gjennomgånde tendens i Hartungs bok at han i flere deler nærmest synes å forholde seg til én kilde av gangen, og dette gir boken tidvis et noe uselvstendig preg. De utvalgte aspekter ved kirkehistorien som belyses, later i stor grad til å være styrt av tekstsamlingen Die Orthodoxe Kirche in Russland. Dokumente ihrer Geschichte (860-1980). Bokens kildegrunnlag virker også temmelig tilfeldig sammensatt, ut fra hva forfatteren hadde for hånden. Påfallende mange helt sentrale verk om russiske kirkehistorie, teologi og spiritualitet er utelatt i bibliografien.

Det er også merkelig at boken ikke omtaler det betydeligste russiske bidraget til 1900-tallets teologi. Jeg sikter her til den såkalte Paris-skolen, som har hatt innflytelse langt utenfor den ortodokse kirkes rekker. Dette teologiske fagmiljøet var sentrert om det anerkjente Saint-Serge-instituttet i Paris, som ble grunnlagt av den russiske eksilkirken i 1925. Sentrale navn her var Sergej Bulgakov (1871-1944), Nikolaj Afanasiev (1893-1966), Vladimir Lossky (1903-1958), Georges Florovsky (1893-1979), Alexander Schmemann (1921-83) og John Meyendorff (1926-1992). De tre sistnevnte flyttet videre til USA. Dersom Hartung har valgt å overse disse kjente teologene fordi de oppholdt seg utenfor Russlands geografiske grenser, burde han i det minste ha argumentert for utelatelsen. De var alle forankret i den russisk-ortodokse tradisjonen og 


\section{4 |CAROLINE SERCK-HANSSEN}

bidro sterkt til å gjøre ortodoks teologi kjent i Vesten. Når forfatteren har viet 17 sider av boken til en presentasjon av fem sentrale bysantinske kirkefedre, kunne han saktens også ha kostet på seg å inkludere de russiske emigrantene.

Upresise formuleringer og en del mindre faktafeil bidrar til at dette ambisiøse verket dessverre ikke fremstår som helt etterrettelig. For å ta noen eksempler: Øygruppen Solovki i Kvitsjøen er blitt lagt til Sibir, og den utbredte påstanden om at Rasputin var munk, gjentas også her, skjønt han i virkeligheten var en gift (om enn ikke trofast) familiefar. Det opplyses at Pussy Riots aksjon i Kristus Frelserenkatedralen fant sted under liturgien. Overhodet for den nyopprettede Ukrainas ortodokse kirke, metropolitt Epifanij av Kiev, blir titulert som patriark. Når disse og andre mangler er påpekt, danner Den ortodokse arv. Perspektiver på Ruslands teologiske tradisjon uansett en overveldende inngangsportal til et kunnskapsfelt som blir stadig mer relevant for å forstå utviklingen i Russland. 